\title{
A new look at old material: ceramic petrography and Neo/Eneolithic pottery traditions in the eastern Ljubljansko barje, Slovenia
}

\author{
Andreja Žibrat Gašparič \\ Department of Archaeology, Faculty of Arts, University of Ljubljana, SI \\ andreja.zibrat.gasparic@gmail.com
}

\begin{abstract}
In this article, a new look at old material, pottery, is presented, as the technology and operational sequences of pottery from the Neolithic and Eneolithic in Slovenia is mostly understudied. Here, the focus is on $5^{\text {th }}$ and $4^{\text {th }}$ millennia BC artefacts from the eastern part of Ljubljansko barje and sites, such as Resnikov prekop, Maharski prekop and Breg near Škofljica. The pottery was studied with a hand lens and petrographically, using an optical polarising microscope. The results were then compared to analyses of locally gathered clays and sediments. Pottery traditions at Resnikov prekop and Breg were different from those at Maharski prekop, although the vessels from all three sites were produced locally and mostly made from local material, but with different recipes or fabrics. The selection of raw material, the shaping and decorating of pots, their firing and use were probably more related to different traditions and individual choices of potters at these sites than to purely technological choices.
\end{abstract}

IZVLEČEK - V članku predstavljam nov pogled na star material, lončenino, saj se tehnologiji in operacijskim sekvencam pri izdelavi lončenine iz obdobja neolitika in eneolitika $v$ Sloveniji posveča le majhna pozornost. Pričujoča analiza je osredotočena na artefakte 5. in 4. tisočletja BC. Iz vzhodnega dela Ljubljanskega barja, ki so bili izkopani na najdiščih Resnikov prekop, Maharski prekop in Breg pri Škofljici. Lončenino smo preiskali na makroskopskem nivoju in s petrografsko metodo opazovanja pod optičnim polarizacijskim mikroskopom. Rezultate smo primerjali z analizami lokalnih glin in sedimentov. Lončarske tradicije se na najdiščih Resnikov prekop in Breg razlikujejo od tradicij na Maharskem prekopu po svojih lončarskih masah in receptih, kljub temu da so bile posode izdelane iz lokalnih materialov. Izbor naravnih materialov, oblikovanje in okraševanje posod, žganje in uporaba so verjetno povezani z različnimi tradicijami in individualnimi odločitvami lončarjev na teh najdiščih in ne prestavljajo izključno le tehnološke rešitve.

KEY WORDS - Ljubljansko barje; Neolithic/Eneolithic; pottery technology; petrography; chaîne opératoire

\section{Introduction}

The Ljubljansko barje is a very intriguing place. This floodplain located to the south of the Slovenian capital, Ljubljana, has been a focus for archaeologists for more than a hundred years. In the Neolithic and Eneolithic, many settlements were erected on the floodplain, mostly in the tradition of so-called piledwellings, and these sites were present in this area at least from the $6^{\text {th }}$ millennium calBC to the Early Bronze Age. Besides this long occupational sequence and similar building techniques, considerable differences may be observed in the material culture, especially in the different pottery traditions (e.g., Bregant 1964; Korošec 1964; Korošec, Korošec 1969; Bregant 1974a; 1974b; 1975; Harej 1975; 1978; 1981-82; 1987; Velušček 2004; 2006; 2009 etc.). Ljubljansko barje is also a subject of continuous debate over the existence or non-existence of a Holocene lake and the interpretation of Neolithic-Eneoli- 
thic pile-dwellings (e.g., Melik 1946; Velušček 2004; 2007; Verbič 2011 contra Budja 1995; Mlekuž et al. 2006; Budja, Mlekuž 2008; 2010). Despite all the controversy surrounding these finds, the area has always been part of extensive studies covering many fields of research since the first excavations; from palynology to dendrochronology, from archaeozoology to material culture studies (e.g., Šercelj 1966; 1974; 1975; Strmole 1974; Osterc 1975; Stritar 1975; Golyeva 2006; Turk 2006; 2009; Bernardini 2009 etc.). With the vast scope of research it is surprising that the most common artefacts at these sites, namely pottery, are the most understudied material in terms of technology. Besides basic descriptions of colour, inclusions and general appearance, typological studies have been prevalent, and only some samples from Maharski prekop and Resnikov prekop have been studied with petrography and X-ray diffraction (Osterc 1975).

In this article, a new look into old material, ceramics, is presented. The observations and results are based on studies of pottery samples from three Neolithic/ Eneolithic sites in Ljubljansko barje: Resnikov prekop, Maharski prekop and Breg near Škofljica. The samples were studied by hand specimen analysis and grouped according to their sand-sized inclusions. Later samples for were chosen for petrographical analysis, prepared as thin sections. The pottery was then ordered into various fabrics that can also be interpreted as the recipes of potters at these sites. In the last stage, these results were compared to analyses of locally gathered clays and sediments. The ceramic vessels are presented as part of an operational sequence or chaîne opératoire in pottery preparation in the Neolithic and Eneolithic period of the eastern Ljubljansko barje region, and their role in the complexity of people's lives is also investigated.

\section{Archaeological sites and samples}

\section{Resnikov prekop}

Resnikov prekop is one of the oldest Neolithic sites in central Slovenia and was discovered during excavations for a new canal near Ig on the Ljubljansko barje in 1953 (Fig. 1). In 1957, Staško Jesse excavated two trenches, one on each side of the canal; the results of his excavation were published later, in the 1970s (Harej 1975). The most extensive excavations were carried out in 1962 by Josip Korošec (Bregant 1964; Korošec 1964). A small number of vertical and horizontal wooden piles was discovered, as well as fragments of branches, stone slabs and plaster fragments. A great amount of pottery, 8 stone axes and some silex tools were also found (Korošec 1964.34). In 2002, the Institute of Archaeology in Ljubljana excavated trenches at Resnikov prekop, south of Korošec's excavation area, where mostly pottery was found (Velušček 2006). The excavation confirmed the observations from the 1960s that the cultural layer at the site had been swept away and the finds represent artefacts from different periods mixed together (Budja 1994/1995.167; Velušček 2006.57). Only heavier artefacts, such as pottery, stones, larger bones and vertical piles probably remained in their original positions at the site.

The piles, although only a few of them have been excavated, show rows that ran in a southwest-northeast direction typical of Ljubljansko barje. In comparison with other so-called pile-dwelling sites on the Ljubljansko barje, Resnikov prekop has fewer piles and the buildings were poorly maintained. This led to the conclusion that the site was occupied for only a short period, perhaps less than a decade (Velušček 2006.57). According to the radiocarbon dates of vertical piles, the existence and duration of the Resnikov prekop site was placed firmly in the $46^{\text {th }}$ century calBC (Čufar, Korenčič 2006.124, Tab. 2). Nevertheless, new radiocarbon dates from charred organic residues on pottery show that the occupation at Resnikov prekop had a longer time span, lasting from around 5300 to 4400 calBC (see Mlekuž et al. 2013).

\section{Maharski prekop}

This site was also discovered in 1953, at a location $\mathrm{Na}$ Mahu near the Maharski prekop canal (Fig. 1). Systematic excavations began in 1970 by Tatjana Bregant and the Department of Archaeology at the University in Ljubljana and continued for several seasons until 1977 (Bregant 1974a; 1974b; 1975; with unpublished material from seasons 1976 and 1977). The excavated area was more than $1100 \mathrm{~m}^{2}$ and the finds were documented in $4 \mathrm{x} 4 \mathrm{~m}$ grid squares (Bregant 1975.9-10). The results of these excavations and recent geomorphological assessments using LiDAR show that Maharski prekop is located on a floodplain with several paleochannels and an active river channel near the site (Mlekuž et al. 2006; Budja, Mlekuž 2008). The site had a distribution of more than 2400 wooden piles, clay floors and grindstones, which were interpreted as the remains of 9 houses, approx. 4 x 10m in size (Mlekuž et al. 2006). New radiocarbon dates show that the occupation at $\mathrm{Ma}$ harski prekop had roughly two phases: one dated between 4400 and $4000 \mathrm{calBC}$ and the other between 3800 and 3550 calBC (Mlekuž et al. 2012.Fig. 2). 


\section{Breg near Škofljica}

This site was discovered during a topographic survey and is located on a small isolated hill called Breg near the small town of Škofliica in the south-eastern part of Ljubljansko barje (Fig. 1). In the years 1983 to 1984 two small trenches, $2 \times 2 \mathrm{~m}$, were excavated by Franc Osole and his team; the oldest layers were dated to the castelnovien or younger Mesolithic period (Frelih 1986.3536). The excavations yielded more than 2500 different stone tools, such as scrapers, blades, burins, cores and other types of flake (Frelih 1986.27). These layers were also radiocarbon dated, but the published dates are confusing, since different dates are given for the same samples (see $\mathrm{Bu}$ dja 1993.175). The second excavation was led by Mihael Budja in the

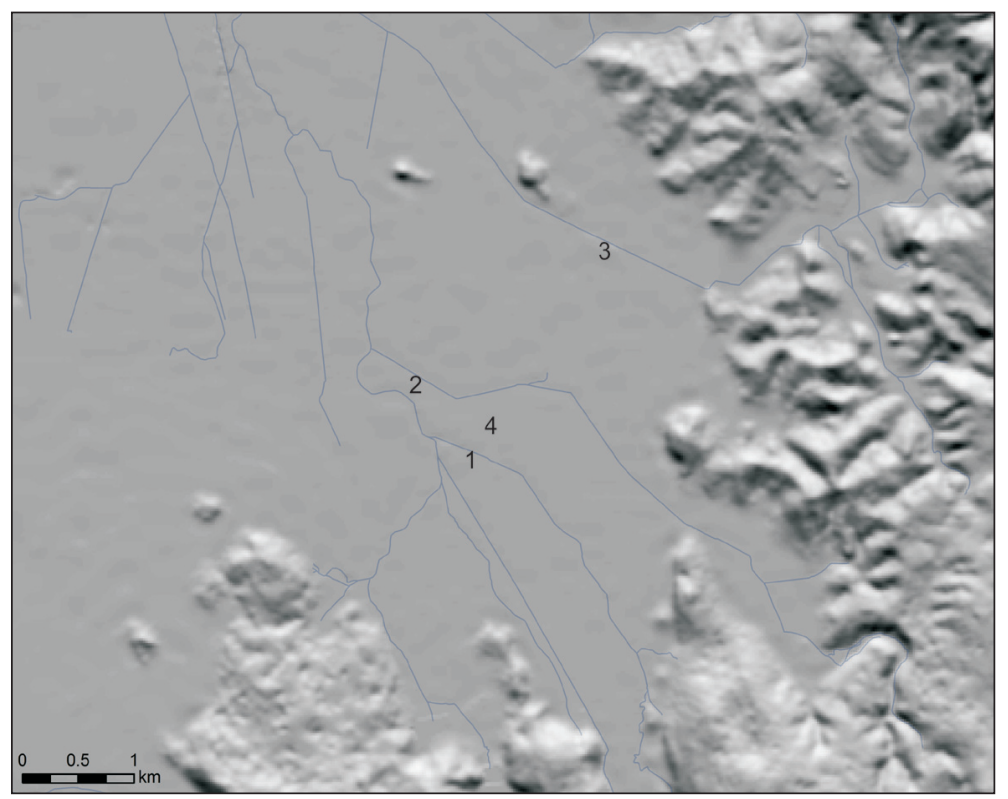

Fig. 1. Map of the eastern part of Ljubljansko barje showing the locations of sites mentioned in the text: 1 Resnikov prekop; 2 Maharski prekop; 3 Breg near Škofljica; 4 Gornje mostišče. 1990s, and again two small trenches, $2 \times 2 \mathrm{~m}$, were excavated (trench II in1996 and trench I in 1997). Pottery fragments were excavated in the oldest layer, together with typical Mesolithic geometrical tools (Tomaž 1999.58-73; Budja, Mlekuž 2008).

\section{Analytical methods}

To identify the pottery technology and the operational sequence or chaîne opératoire, the pots were first sampled according to their stratigraphic position, vessel type and ornamentation techniques at each site. The samples were then analysed using a hand lens and following descriptions of pottery published by Milena Horvat (1999). Such hand specimen analyses enabled the characterisations of broader technological traits for large pottery assemblages. The basic composition of the pots was described, i.e. their inclusions, the abundance and size of the particles and the presence of voids; the hardness, surface colour, firing atmosphere and surface treatment were also recorded. The samples were then grouped into different fabric types, which enabled us to select samples for petrographic analysis. The petrographic description of pottery enhances the identification of different non-plastic inclusions and allows for direct comparisons with regional geology (Whitbread 2001.451).

Pottery samples for the petrographic analysis were prepared as standard thin sections of $30 \mu \mathrm{m}$ thickness (Reedy 2008.1-3). The samples were then ana- lysed under a polarising light microscope, following the descriptions proposed by Ian Whitbread (1995. Appendix 3) and the volume estimates were made using tables published by Richard D. Terry and George V. Chillingar (1955). The samples were then sorted into fabric groups, based on the composition of their inclusions, the clay matrix and the voids under the microscope. On the basis of compositional, microstructural and textural criteria, the presence of specific techniques was detected, such as the intentional addition of temper, raw material processing, vessel-forming techniques, and the atmosphere and degree of firing (Reedy 2008.146-148, 173189; Rice 1987.409-411; Whitbread 1986; 1995. 393-394).

In addition, we sampled clays near Resnikov prekop and Maharski prekop. The clay samples were analysed using an X-ray diffractometer in their natural state, and were additionally prepared as approx. 3 $\mathrm{x} 4 \mathrm{~cm}$ plates and fired in a controlled oxidising atmosphere at $700^{\circ} \mathrm{C}$. The fired clay samples were then analysed using the X-ray diffraction technique, made into thin sections and analysed using a polarising light microscope, following a criteria similar to that applied to the pottery samples (Whitbread 1995; Terry, Chillingar 1952).

\section{Pottery technology at Resnikov prekop}

The most common types of vessel found at Resnikov prekop are various pots, followed by dishes, pedestal 
dishes, bowls, cups, jugs, and ladles with cylindrical handles (see Mlekuž et al. 2013). Vessel surfaces were smoothed or burnished, but no surface polishing was detected. These pots were made with the coiling technique, the walls are very fine and less than $5 \mathrm{~mm}$ thick. The vessels were fired in an incomplete oxidising atmosphere, and only rare pots were fired in an oxidising and reducing atmosphere. The dominant colours of the pottery assemblage are grey, dark brown and light red (Korošec 1964.29-30; Harej 1975.147; Tomaž, Velušček 2005.88-90). The most striking feature is the fact that all the ornamentation appears only on the exterior of the upper part of the vessels. The ornaments were made with impressions, incisions or appliqués, or a combination of the three techniques. Some vessels were decorated with a red and, rarely, black slip, that was applied, unlike other ornamentation techniques, to the entire vessel, on the interior and exterior surfaces (Korošec 1964.33; Harej 1975.149; Velušček 2006.5758; Tomaž, Velušček 2005).

For the present study, 120 pottery samples from Resnikov prekop were analysed with a hand lens for the presence of different inclusions, their size and frequency, and the presence of voids. The samples were chosen according to the typology of the published material from the site (Korošec 1964; Harej 1975; Velušček 2006) and were in part used also in the biochemical lipid analysis (see Mlekuž et al. 2013). These vessels could be attributed to three technological groups: the first group of vessels, made from non-calcareous clay and only quartz inclusions (31/120); the second group with quartz and calcite/ limestone inclusions is the most common (59/120); the third comprised mostly calcite/limestone inclusions (30/120). The majority of vessels, i.e. 52.5\%, has inclusions in the size range of medium sand $(0.25$ to $0.50 \mathrm{~mm}$ ) and a further $40.8 \%$ has inclusions in the range of very fine sand (less than $0.25 \mathrm{~mm}$ ). Vessels with coarser sand inclusions $(0.50$ to $2.00 \mathrm{~mm})$ are much less common (6.7\%) and made mostly with quartz and calcite/limestone inclusions belonging to the second technological group.

Various pots, different types of dishes and pedestal dishes from Resnikov prekop share many technological characteristics and are typically made with inclusions of quartz and calcite/limestone, which are in the medium sand fraction. Different types of bowl are similarly made, but nevertheless exhibit a stronger presence of vessels made only with quartz inclusions and much more fine-grained fabrics, with fine sand inclusions.

\section{Petrographic analysis of the Resnikov prekop pottery}

For the petrographic analysis of pottery from Resnikov prekop, 25 samples were chosen and prepared as standard thin sections (Tab. 1). All samples were chosen according to the technological characteristics observed in the hand specimen description (see above) covering all the different technological groups. These samples can be attributed to eight different fabric groups according to the characteristics of clays and inclusions, as well as temper added by the potters at Resnikov prekop (Tab. 2, Fig. 2).

Fabric RP-1 (Fig. 2.A) is a very fine-grained non-calcareous clay with frequent (40\%) non-plastic inclusions, with a few sponge spicules present in the paste. The clay appears to be only cleaned of coarser inclusions and no temper was added. The inclusions are well sorted and mostly in the silt size fraction. The inclusions are frequent monocrystalline quartz, frequent muscovite and very rare biotite mica, a few sponge spicules, rare chert grains, common opaques or 'amorphous' concentration features (see Whitbread 1995.380) and very rare feldsparsplagioclase grains (Tab. 2). The fabric could be identified in three samples from the Jesse trench I excavated in 1957 (Harej 1975), but was not present in any of the other trenches.

Fabric RP-2 (Fig. 2.B) is also a very fine-grained noncalcareous clay, with common (20\%) non-plastic inclusions with frequent opaques. The clay was only cleaned of coarser inclusions, since no temper was added by the potters. The inclusions are mostly well sorted and have grains in the silt size fraction. The inclusions are frequent monocrystalline quartz, rare chert grains, common muscovite and a few biotite mica, with very rare sandstone grains and very rare argillaceous rock fragments (see Whitbread 1986) (Tab. 2). The fabric was identified in five samples from all excavated trenches and came from vessels such as pots, dishes and pedestal vessels (e.g., Korošec 1964.T. 10.7).

Fabric RP-3 (Fig. 2.C) has a coarser texture and is a non-calcareous clay with common (20\%) non-plastic inclusions and chert, probably added as temper. The chert grains are common (10\%), semi-angular and medium sorted, mostly in the fine to medium sand fraction, and could have been added as temper by the potters. The other inclusions include frequent monocrystalline quartz, frequent muscovite and very rare biotite mica, a few opaques and very rare argillaceous rock fragments (Tab. 2). The fabric could be 


\begin{tabular}{|c|c|c|c|c|c|c|c|}
\hline $\begin{array}{l}\text { Sample } \\
\text { No. }\end{array}$ & Site & $\begin{array}{c}\text { Year of } \\
\text { excavation }\end{array}$ & $\begin{array}{c}\text { Grid } \\
\text { square }\end{array}$ & Context & Vessel type & $\begin{array}{l}\text { Fabric } \\
\text { group }\end{array}$ & Citation \\
\hline$\overline{\mathrm{RP}} 5$ & Resnikov prekop & 1957 & & & deep dish & $R P-5$ & Harej 1975.T. 2.10 \\
\hline $\mathrm{RP} 15$ & Resnikov prekop & 1957 & & & pot & $\mathrm{RP}-2$ & Harej 1975.T. 6.8 \\
\hline $\mathrm{RP}_{20}$ & Resnikov prekop & 1957 & & Trench 1 & small pot & $\mathrm{RP}-1$ & Not published \\
\hline RP21 & Resnikov prekop & 1957 & & Trench 1 & small pot & $\mathrm{RP}-1$ & Not published \\
\hline $\mathrm{RP} 22$ & Resnikov prekop & 1957 & & Trench 1 & cup & $\mathrm{RP}-1$ & Not published \\
\hline RP23 & Resnikov prekop & 1957 & & Trench 1 & small pot & $\mathrm{RP}-2$ & Not published \\
\hline $\mathrm{RP} 24$ & Resnikov prekop & 1957 & & Trench 1 & pot & $R P-5$ & Not published \\
\hline $\mathrm{RP}_{30}$ & Resnikov prekop & 1962 & & & pot & $R P-5$ & Korošec 1964.T. 18.1 \\
\hline $\mathrm{RP}_{34}$ & Resnikov prekop & 1962 & & & bowl & $\mathrm{RP}-8$ & Not published \\
\hline $\mathrm{RP}_{35}$ & Resnikov prekop & 1962 & & & pedestal dish & $\mathrm{RP}-3$ & Not published \\
\hline RP44 & Resnikov prekop & 1962 & & & dish & $\mathrm{RP}-2$ & Korošec 1964.T. 10.7 \\
\hline RP5O & Resnikov prekop & 1962 & & & pedestal dish & $\mathrm{RP}-6$ & Korošec 1964.T. 15.4 \\
\hline RP73 & Resnikov prekop & 1962 & & & bowl? & $\mathrm{RP}-8$ & Not published \\
\hline RP79 & Resnikov prekop & 2002 & 11 & Trench $1 / \mathrm{SU}$ oO5 & pot & RP-8 & Not published \\
\hline RP84 & Resnikov prekop & 2002 & 9 & Trench $1 / \mathrm{SU} 005$ & pot & $R P-5$ & Not published \\
\hline RP85 & Resnikov prekop & 2002 & 4 & Trench 2/SU oo5 & pot & $\mathrm{RP}-6$ & Velušček 200G.T. 13.3 \\
\hline RP89 & Resnikov prekop & 2002 & 11 & Trench $1 / \mathrm{SU} 005$ & pedestal vessel & $\mathrm{RP}-2$ & Not published \\
\hline RP91 & Resnikov prekop & 2002 & 11 & Trench $1 / \mathrm{SU}$ oO5 & pot & $\mathrm{RP}-7$ & Not published \\
\hline RP92 & Resnikov prekop & 2002 & 1 & Trench 2/SU oO5 & pedestal vessel & $R P-5$ & Not published \\
\hline RP98 & Resnikov prekop & 2002 & 9 & Trench 3/SU oO5 & pedestal dish & $\mathrm{RP}-6$ & Velušček 2006.T. 19.4 \\
\hline RP100 & Resnikov prekop & 2002 & 9 & Trench 3/SU oo5 & bowl & $\mathrm{RP}-8$ & Velušček 2006.T. 19.1 \\
\hline RP107 & Resnikov prekop & 2002 & 8 & Trench 3/SU oO5 & pot & $\mathrm{RP}-6$ & Not published \\
\hline RP108 & Resnikov prekop & 2002 & 8 & Trench $3 / \mathrm{SU}$ oO5 & pot & $\mathrm{RP}-2$ & Not published \\
\hline RP110 & Resnikov prekop & 2002 & 7 & Trench 2/SU o05 & deep dish & $\mathrm{RP}-7$ & Velušček 2006.T. 15.1 \\
\hline RP111 & Resnikov prekop & 2002 & 7 & Trench 2/SU oO5 & dish & $\mathrm{RP}-4$ & Velušček 200G.T. 14.18 \\
\hline $\mathrm{MP} 22$ & Maharski prekop & 1974 & 17 & & pot & $\mathrm{MP}-1$ & Bregant 1975.T. 15.4 \\
\hline $\mathrm{MP} 26$ & Maharski prekop & 1973 & 18 & & pot & $\mathrm{MP}-1$ & Bregant 1975.T. 16.1 \\
\hline MP47 & Maharski prekop & 1973 & 23 & & pot & $\mathrm{MP}-1$ & Bregant 1975.T. 22.6 \\
\hline MP55 & Maharski prekop & 1973 & 24 & & pot & $\mathrm{MP}-1$ & Bregant 1975.T. 23.9 \\
\hline MP79 & Maharski prekop & 1974 & 27 & & dish & $\mathrm{MP}-1$ & Bregant 1975.T. 29.2 \\
\hline $\mathrm{MP1O} 3$ & Maharski prekop & 1974 & 37 & & pot & $\mathrm{MP}-1$ & Bregant 1975.T. 35.10 \\
\hline MP1O4 & Maharski prekop & 1974 & 37 & & pot & $\mathrm{MP}-1$ & Bregant 1975.T. 36.2 \\
\hline MP199 & Maharski prekop & 1977 & 71 & & bowl & $\mathrm{MP}-1$ & Not published \\
\hline $\mathrm{MP206}$ & Maharski prekop & 1970 & $1-8$ & & bowl & $\mathrm{MP}-1$ & Not published \\
\hline MP211 & Maharski prekop & 1970 & $1-8$ & & pot & $\mathrm{MP}-1$ & Not published \\
\hline $\mathrm{MP} 13$ & Maharski prekop & 1972 & 13 & & pot & $\mathrm{MP}-2$ & Bregant 1974b.T.6.17 \\
\hline MP133 & Maharski prekop & 1972 & 13 & & pot & $\mathrm{MP}-2$ & Not published \\
\hline $\mathrm{MP147}$ & Maharski prekop & 1976 & 44 & & pot & $\mathrm{MP}-3$ & Not published \\
\hline $\mathrm{MP}_{148}$ & Maharski prekop & 1976 & 44 & & pot & $\mathrm{MP}-3$ & Not published \\
\hline $\mathrm{MP185}$ & Maharski prekop & 1977 & 68 & & pot & $\mathrm{MP}-4$ & Not published \\
\hline $\mathrm{BR} 1$ & Breg near Škofljica & 1997 & 3 & SU o6 & pot & $\mathrm{B}-1$ & Tomaž 1999.T. B1.9 \\
\hline $\mathrm{BR} 5$ & Breg near Škofljica & 1997 & 3 & SU O7 & pot & $B-3$ & Not published \\
\hline BR6 & Breg near Škofljica & 1997 & 4 & $\mathrm{SU} 03 / 3$ & pot & $B-2$ & Not published \\
\hline $\mathrm{BR7}$ & Breg near Škofljica & 1997 & 4 & SU O7 & pot & $B-1$ & Not published \\
\hline
\end{tabular}

Tab. 1. List of pottery and clay samples presented in the article.

identified in only one thin section from a deep dish, with an appliqué from Korošec's trench (unpublished, similar to Korošec 1964.T. 7.1).

Fabric RP-4 (Fig. 2.D) has a fine texture and is a noncalcareous clay with a few (10\%) non-plastic inclusions and chert, probably added as temper. The chert grains are common, semi-angular and medium sorted, mostly in the sand fraction up to $1.5 \mathrm{~mm}$, and could have been added as temper by the potters. The other inclusions include frequent monocrystalline quartz, very rare sandstone grains, a few muscovite and very few biotite mica, a few opaques and very few clay pellets (Tab. 2). The fabric could be 
identified in only one thin section from a bowl from trench 2, excavated in 2002 (Velušček 2006.T. 14. 18).

Fabric RP-5 (Fig. 2.E) is a coarsegrained non-calcareous clay with frequent (30-40\%) non-plastic inclusions. The inclusions are medium sorted, and especially quartz, sandstone and limestone grains are in the medium to coarse sand and even gravel fraction (more than $2 \mathrm{~mm}$ ). The inclusions include dominant monocrystalline quartz, frequent muscovite and very few biotite mica, very few sandstone and calcareous sandstone, very rare limestone, very few chert, a few opaques and very rare plagioclase feldspars (Tab. 2). It is not clear if the coarse quartz, sandstone, calcareous sandstone and limestone grains were intentionally added to the clay as temper, since the overall fabric and opaques or 'amorphous' concentration features can also be quite coarse in these samples. The samples made with this fabric come mostly from pots, as well as from pedestal vessels and bowls with a red slip (e.g., Harej 1975.T. 2.10).

Fabric RP-6 (Fig. 2.F) is a non-calcareous clay with a few (10\%) nonplastic inclusions. The inclusions are predominantly monocrystalline quartz, common muscovite and very few biotite mica, very few limestone grains, rare sandstone and chert, common opaques and very rare plagioclase feldspars (Tab. 2). The quartz, sandstone and chert grains
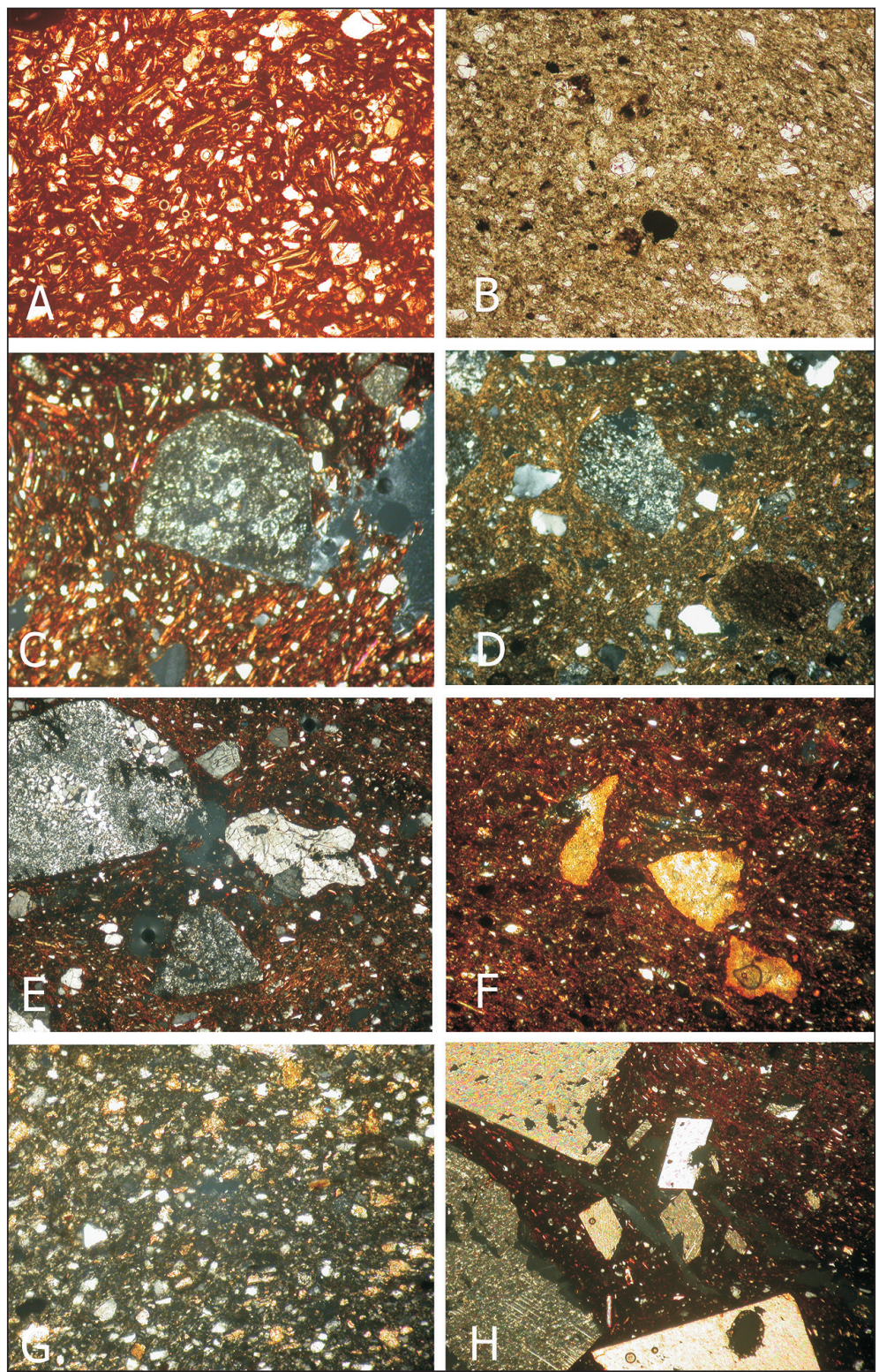

Fig. 2. Photomicrographs of the petrographic fabric groups detected at Resnikov prekop: $A$ - fabric group RP-1; B - fabric group $R P-2 ; C$ - fabric group RP-3; D - fabric group RP-4; $E$ - fabric group $R P-5 ; F$ - fabric group RP-6; $G$ - fabric group $R P-7 ; H$ - fabric group $R P-8$. Images $A-B$ taken in plane polarised light; image width is $1 \mathrm{~mm}$. Images $\mathrm{C}-\mathrm{H}$ taken in crossed polars; image width is $2 \mathrm{~mm}$ (photo by the author). are well sorted and mostly in the silt to fine sand fraction, and limestone grains are medium to poorly sorted, in the medium to coarse sand fraction. Limestone could have been added as temper to the clay paste according to the size, shape and sorting of the grains. The fabric is present in dishes, pedestal dishes and pots (Korošec 1964.T. 15.4; Velušček 2006.T. 13.3, T. 19.4).

Fabric RP-7 (Fig. 2.G) is a non-calcareous clay with common (20\%) non-plastic inclusions The inclusions are well to medium sorted and mostly in the silt fra- ction; the quartz and limestone grains can be up to coarse sand fraction. The inclusions are predominantly monocrystalline quartz, common limestone, few muscovite and rare biotite mica, rare sandstone, very rare chert, very rare plagioclase feldspars and a few opaque grains (Tab. 2). The limestone is subrounded, well sorted and mostly in silt-size fractions, meaning it is a natural inclusion in the clay paste. The fabric is typical of dishes and pots, and found only in vessels excavated in Velušček's trench (e.g., Velušček 2006.T. 15.1). 


\begin{tabular}{|c|c|c|c|c|c|c|c|c|c|c|}
\hline $\begin{array}{l}\text { Fabric } \\
\text { groups }\end{array}$ & Sample No. & $\begin{array}{l}\text { Calcite } \\
\text { (in \%) }\end{array}$ & $\begin{array}{l}\text { Limestone } \\
\text { (in \%) }\end{array}$ & $\begin{array}{l}\text { Sandstone } \\
\text { (in \%) }\end{array}$ & $\begin{array}{l}\text { Spicules } \\
\text { (in \%) }\end{array}$ & $\begin{array}{l}\text { Quartz } \\
\text { (in \%) }\end{array}$ & $\begin{array}{l}\text { Chert } \\
\text { (in \%) }\end{array}$ & $\begin{array}{l}\text { Muscovite } \\
\text { (in \%) }\end{array}$ & $\begin{array}{l}\text { Biotite } \\
\text { (in \%) }\end{array}$ & $\begin{array}{c}\text { Opaques } \\
\text { (in \%) }\end{array}$ \\
\hline Fabric RP-1 & $\mathrm{RP}_{20}, \mathrm{RP}_{21}, \mathrm{RP}_{22}$ & 0 & 0 & 0 & $5^{-15}$ & $30-35$ & $0.5^{-2}$ & $35-40$ & $<0.5$ & $10-25$ \\
\hline Fabric RP-2 & $\begin{array}{l}\mathrm{RP}_{15}, \mathrm{RP}_{23}, \mathrm{RP}_{44}, \\
\mathrm{RP} 89, \mathrm{RP}_{108}\end{array}$ & O & O & $<0.5$ & O & $30-45$ & $0.5^{-2}$ & $15-30$ & $2-15$ & $30-50$ \\
\hline Fabric RP-3 & $\mathrm{RP}_{35}$ & O & O & O & O & 40 & 10 & 35 & $<0.5$ & 15 \\
\hline Fabric RP-4 & RP111 & O & O & $<0.5$ & O & 50 & 10 & 15 & $2-5$ & 15 \\
\hline Fabric RP-5 & $\begin{array}{l}\mathrm{RP}_{5}, \mathrm{RP}_{24}, \mathrm{RP}_{30} \\
\mathrm{RP} 84, \mathrm{RP}_{92}\end{array}$ & O & $<0.5$ & $1-5$ & O & $45-60$ & $1-5$ & $30-45$ & $2-5$ & $5^{-15}$ \\
\hline Fabric RP-6 & $\begin{array}{l}\mathrm{RP}_{50}, \mathrm{RP}_{85}, \mathrm{RP}_{98} \\
\mathrm{RP}_{107}\end{array}$ & O & $1-5$ & $0.5^{-1}$ & O & $40-50$ & $0.5^{-2}$ & $15-40$ & $0.5-3$ & $10-25$ \\
\hline Fabric RP-7 & RP91,RP110 & 0 & $20-40$ & 1 & O & 40 & $<0.5$ & $2-10$ & $0.5^{-2}$ & $5-10$ \\
\hline Fabric RP-8 & $\begin{array}{l}\mathrm{RP}_{34}, \mathrm{RP} 73, \mathrm{RP} 79 \\
\mathrm{RP} 100\end{array}$ & $10-25$ & O & O & O & $40-50$ & $<0.5$ & $15-35$ & $0.5-3$ & 10 \\
\hline
\end{tabular}

Tab. 2. The basic mineralogical composition of the eight fabric groups typical of the Resnikov prekop pottery.

Fabric RP-8 (Fig. 2.H) is a non-calcareous clay with added calcite as temper with common to frequent (20-30\%) non-plastic inclusions. The natural present inclusions are well sorted, mostly in the silt fraction, and consist mainly of monocrystalline quartz, common muscovite and rare biotite mica, very rare chert and a few opaque grains (Tab. 2). The calcite grains are common, angular, poorly sorted to unsorted and mostly in the fine to coarse sand range; two samples (RP73, RP79) also have calcite grains in the gravel fraction. Calcite temper was added by the potters in at least $(30 / 120)$ the vessels from Resnikov prekop (see above). Various vessel types such as pots, dishes, bowls and ladles were made from this fabric (e.g., Velušček 2006.T. 19.1), but the fabric is very rare to absent in other types, such as jugs.

The fabrics have the characteristics of at least four different natural non-calcareous clay pastes: one paste is very fine grained with sponge spicules (fabric RP-1); the second paste is very fine grained, with frequent opaque minerals (fabric RP-2); the third paste has many natural limestone inclusions and only a few mica grains (fabric RP-7), and the fourth paste has naturally occurring concentrations of chert, sandstone and limestone grains in the silt fraction (fabrics RP-3, RP-4, RP-5, RP-6 and RP-8). Potters prepared these pastes in different recipes, for example with no added temper, as in fabrics RP-1, $\mathrm{RP}-2$ and RP-7, and with added chert (fabric RP-3, $\mathrm{RP}-4)$, sandstone (RP-5), limestone (RP-6) and calcite (RP-8) temper to mostly the same naturally occuring clay paste. Therefore, potters made vessels with no temper, using different types of paste; on the other hand, they added various natural inclusions as temper to similar pastes. This shows a variety of technological solutions by these potters in the preparation of the clay body; nevertheless, the forming, decorating and firing techniques of Resnikov prekop pottery were quite similar for most of the vessels made at this site.

\section{Pottery technology at Maharski prekop}

We recently analysed the pottery from Maharski prekop excavated from 1970 to 1977 (Bregant 1974a; 1974b; 1975; and unpublished material), using a more holistic approach and combining the technology, typology, function and direct dates of the vessels (Mlekuž et al. 2012; Ogrinc et al. 2012). As many as 349 whole or reconstructed vessels were classified according to typological categories (after Horvat 1999) and their capacity into five vessels groups (Mlekuž et al. 2012.332-334, Fig. 9-10). We concluded that most of the pottery shows individual use for consumption or preparation of food for a smaller group of people, since vessels with volumes from 0.5 to 21 were the most common at the site. Large vessels used for the preparation and serving of food for larger groups of people were rare (Mlekuž et al. 2012.333). The vessels were also analysed for their lipid content by gas chromatographymass spectrometry (GC-MS), gas chromatographycombustion-isotope ratio mass spectrometry (GC-CIRMS) and soft ionisation electrospray mass spectrometry techniques ESI Q-TOF MS. The results show that the vessels contained residues of ruminant animal fats; many of the pots also show traces of mixed animal and plant fats. In two vessels, traces of goat milk could be identified (Ogrinc et al. 2012).

For the study of pottery technology, we analysed 222 pottery samples from Maharski prekop excavated between 1970 and 1977. The hand specimen analysis showed a great homogeneity in pottery fabrics and recipes. The majority of vessels are made 
with abundant calcite grains in the clay paste, which is characteristic of more than $95 \%$ of the vessels (Mlekuž et al. 2012.334-335). The pottery was mostly fired in a reducing or incomplete oxidised atmosphere; the most common surface colour is dark grey; the surfaces of the vessels are burnished, and the pottery is mostly soft (Mohs scale 2-4). The vessels were all hand made using the coiling technique. All these characteristic give this pottery assemblage a very homogenous appearance (Bregant 1974a.1920; 1974b.50-52; 1975.34-35).

\section{Petrographic analysis of the Maharski prekop pottery}

For the petrographic analysis, 15 samples from Maharski prekop were prepared as standard thin sections. The samples were chosen according to the characteristics observed in the hand specimen analysis (Tab. 1). The analysed samples could be classified into four different fabrics according to the temper and the mineralogical composition of the natural clay paste and non-plastic inclusions (Tab. 3, Fig. 3A-3D).

Fabric MP-1 (Fig. 3.A) is a non-calcareous clay with frequent $(30 \%)$ non-plastic inclusions and calcite grains added as temper. The naturally present inclusions are well sorted and mostly in the silt size fraction. They consist of common to frequent monocrystalline quartz, a few muscovite and very few biotite mica, very rare chert, a few opaques, very rare argillaceous rock fragments, a few grains of organic matter, very rare calcareous sandstone and very rare plagioclase feldspars (Tab. 3). Calcite grains are frequent to dominant, angular, poorly sorted to unsorted and mostly in the fine to coarse sand fraction. The majority of the Maharski prekop pottery was made with this fabric; the fabric is typical of most of the vessel shapes, predominant in all of the excavated houses and from all of the phases, according to the radiocarbon dates.

Fabric MP-2 (Fig. 3.B) is a non-calcareous clay with frequent $(30 \%)$ non-plastic inclusions and crushed pottery (grog) and calcite grains added as temper. The naturally present inclusions are well sorted and mostly in the silt size fraction. They consist of common monocrystalline quartz, a few muscovite and rare biotite mica, very rare chert, very few opaque grains, very rare argillaceous rock fragments and a few grains of organic matter (Tab. 3). Calcite grains are common, angular, poorly sorted and mostly in the fine to coarse sand fraction. The main characteristic of this fabric is the presence of crushed pottery or grog. The grog grains are semi-angular, poorly sorted and present in the fine sand to coarse sand fraction. The mineralogical compositions of grog are similar to fabric MP-1, which proves that the potters re-used old or damaged pottery as tempering material in addition to crushed calcite grains, which comprised the most common temper at the site. Apart from grog, the non-plastic inclusions and calcite temper of this fabric are similar to fabric MP-1. Fabric MP-2 is rare at the site, and present mostly around house No. 4, which is attributed to the younger occupation phase and was used for making pots (e.g., Bregant 1974b.T. 6.17).

Fabric MP-3 (Fig. 3.C) is a non-calcareous clay with few $(10 \%)$ non-plastic inclusions. The inclusions are frequent monocrystalline quartz, common muscovite and very few biotite mica, a few opaque grains and very rare argillaceous rock fragments. The main characteristic of this fabric is the common presence of organic matter, which was probably added as temper to the natural clay paste (Tab. 3). The fabric is rare at the site, being present in less than $3 \%$ of the vessels, mostly used in the preparation of pots (e.g., Bregant 1975.T. 18.3).

Fabric MP-4 (Fig. 3D) is a non-calcareous clay with few $(10 \%)$ non-plastic inclusions. These include frequent monocrystalline quartz, rare sandstone, very few chert, frequent muscovite and a few biotite mica, a few opaque grains and very rare argillaceous rock fragments (Tab. 3). The quartz, sandstone and chert grains are mostly angular and poorly sorted;

\begin{tabular}{|c|c|c|c|c|c|c|c|c|c|}
\hline $\begin{array}{l}\text { Fabric } \\
\text { groups }\end{array}$ & Sample No. & $\begin{array}{l}\text { Grog } \\
\text { (in \%) }\end{array}$ & $\begin{array}{l}\text { Calcite } \\
\text { (in \%) }\end{array}$ & $\begin{array}{l}\text { Quartz } \\
\text { (in \%) }\end{array}$ & $\begin{array}{l}\text { Chert } \\
\text { (in \%) }\end{array}$ & $\begin{array}{l}\text { Muscovite } \\
\text { (in \%) }\end{array}$ & $\begin{array}{l}\text { Biotite } \\
\text { (in \%) }\end{array}$ & $\begin{array}{l}\text { Organic matter } \\
\quad \text { (in \%) }\end{array}$ & $\begin{array}{c}\text { Opaques } \\
\text { (in \%) }\end{array}$ \\
\hline Fabric MP-1 & $\begin{array}{l}\text { MP22,MP26,MP47, } \\
\text { MP55,MP79,MP103, } \\
\text { MP104,MP199, } \\
M_{206, M P_{211}}\end{array}$ & 0 & $20-50$ & $15-40$ & $0.5^{-1}$ & $10-20$ & $1-5$ & $2-10$ & $5-15$ \\
\hline Fabric MP-2 & $\mathrm{MP}_{13}, \mathrm{MP}_{133}$ & $5-10$ & $15-30$ & $20-30$ & $0.5^{-1}$ & $10-20$ & $1-3$ & $1-5$ & $3-5$ \\
\hline Fabric MP-3 & $\mathrm{MP} 147, \mathrm{MP}_{148}$ & O & o & $30-40$ & $0.5^{-1}$ & $15-30$ & $1-5$ & $20-30$ & $5-10$ \\
\hline Fabric MP-4 & $\mathrm{MP} 185$ & O & O & 40 & 3 & 30 & 5 & O & 10 \\
\hline
\end{tabular}

Tab. 3. The basic mineralogical composition of the four fabric group, typical of the Maharski prekop pottery. 

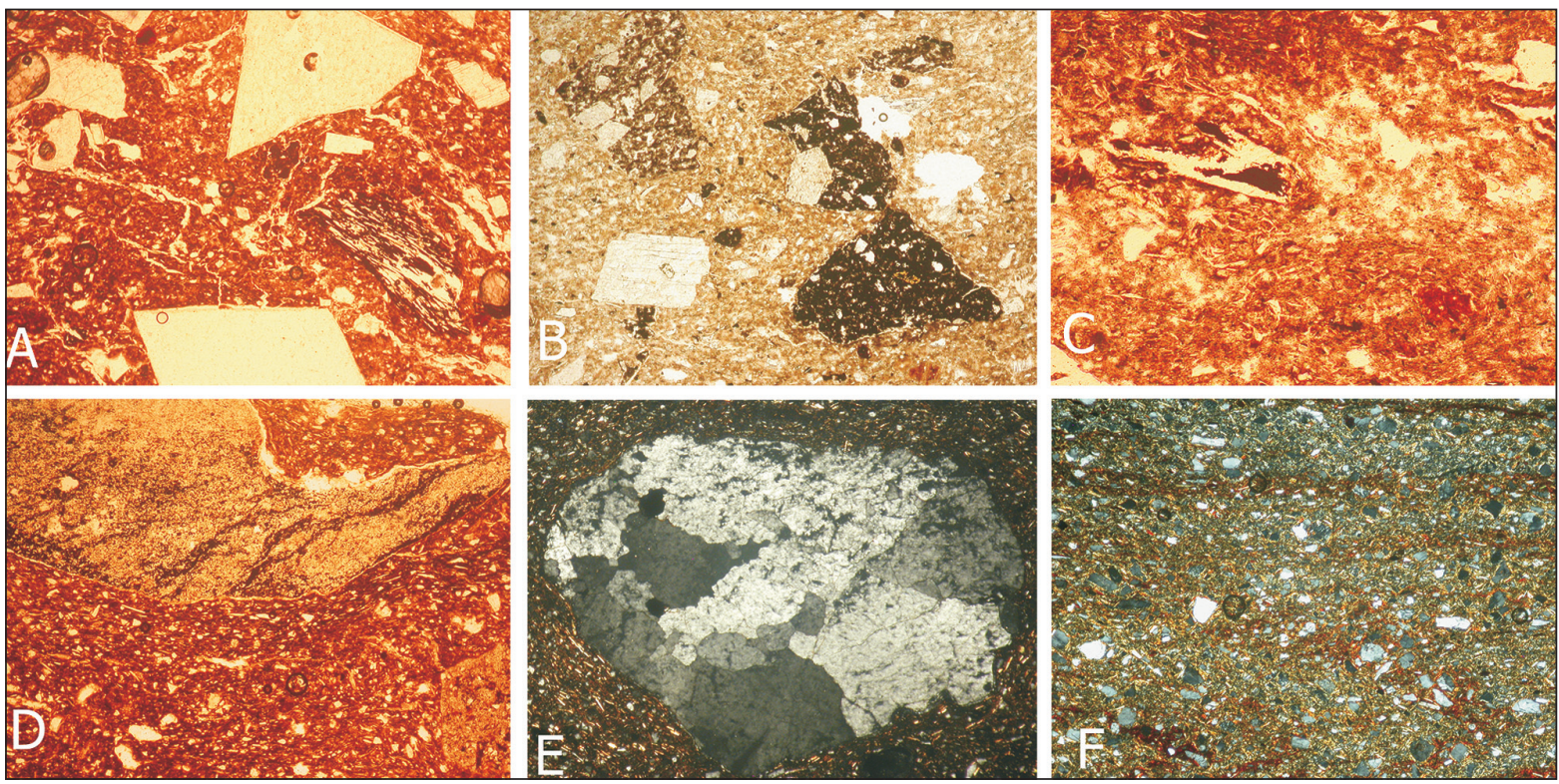

Fig. 3. Photomicrographs of the petrographic fabric groups detected at Maharski prekop, Breg and Gornje mostišče: $A$ - fabric group MP-1; B - fabric group MP-2; C - fabric group MP-3; D - fabric group $M P-4 ; E$ - fabric group BR-2; $F$ - clay sample GM3. Images A-D taken in plane polarised light; images E-F taken in crossed polars. Image width is $2 \mathrm{~mm}$ (photo by the author).

the grains can be up to the coarse sand to gravel fraction. These grains could have been added as temper to the clay paste. The fabric was recognised in only one sample from the analysed vessels and is from a small fragment decorated with incised lines that was fired in an oxidising atmosphere. The fragment is similar to pottery from Resnikov prekop (compare with Korošec 1964.T. 4.6; Harej 1975.T. 2.1, 3, 4; Velušček 2006.T 10.9-14). This fabric differs significantly from the remaining fabric from Maharski prekop, especially in comparison to fabrics MP-1 and MP-2, which could support the idea that rare fragments with similarities to pottery from Resnikov prekop were carried by rivers to Maharski prekop (see also Bregant 1974b.52).

All the fabrics from Maharski prekop have a similar composition of non-plastic inclusions in the clay paste and were therefore made from similar natural clays; the main difference between the fabrics is the type of temper used in pottery preparation techniques. Maharski prekop potters used mostly crushed calcite as temper, but also crushed old pottery or grog; organic materials, quartz, sandstone and chert grains were also used. The majority of pottery, more than $95 \%$, was made with fabric MP-1, in which calcite grains comprise the main tempering material; all the other fabric are represented in less than 5\% of the vessels at Maharski prekop. The technological characteristics, with similar forming, decorating and firing techniques, gives the Maharski prekop pottery a very homogenous appearance and point to a very strong pottery tradition at the site that lasted at least 800 years according to new radiocarbon dates.

\section{Pottery technology at Breg near Škofljica}

Only 65 fragment of pottery were excavated in two trenches at Breg (37 fragments from trench I - 1997 and 28 fragments from trench II - 1996). The pottery shows great diversity in the hand specimen description. Vessels are made either with calcite/limestone grains, with only quartz grains or with a combination of quartz and calcite/limestone. The pottery from trench II has different characteristics from the pots from trench I, where vessels made with abundant calcite/limestone were rare, the surfaces of vessels were mostly smoothed and rarely burnished, the pots were fired in an incomplete oxidising atmosphere, but a reducing atmosphere is also present (Tomaž 1999.58-73). The common characteristics of these pots are the absence of slips and incised decorations. The typological determination of vessels was possible on only two fragments: one pot from trench I and one dish/bowl from trench II (Tomaž 1999.T. B1.1,9). The pottery assemblage from Breg near Škofljica has unique characteristics that set this site apart from the contemporaneous pottery at Resnikov prekop, but the overall generalisation of this observation is not possible, since the Breg pottery assemblage is smaller than the one at Resnikov prekop (Tomaž 1999.73). 


\section{Petrographic analysis of the Breg pottery}

For the petrographic analysis, four samples were chosen from trench I, excavated in 1997, according to their technological characteristics in hand specimen analysis (Tab. 1). The samples could be attributed to three different fabrics according to the distributions of inclusions inside the clay matrix and the composition of non-plastic inclusions.

Fabric BR-1 is typical of two of the Breg samples (BR1 and BR7) that were attributed to different stratigraphic units during excavation, but which exhibit such similarities in thin section analysis, as well as in general appearance and decoration techniques that they could be fragments of the same pot. This fabric is a non-calcareous clay, with common (20\%) non-plastic inclusions. The inclusions are frequent monocrystalline quartz, common muscovite and few biotite mica, rare sandstone and calcareous sandstone, very rare limestone and chert, a few opaque grains, very rare plagioclase feldspars and organic matter (Tab. 4). Most of the inclusions are in the silt fraction, but a smaller amount of quartz and all the sandstone and limestone grains are in the sand fraction. These coarser grains are mostly semi-rounded and well sorted; therefore, they were part of the natural clay paste. Only some rare quartz sand grains are angular and could have been added as temper by the potters. This fabric was the most common in trench I, since $40 \%$ of the fragments shared these characteristics in hand specimen analysis (Tomaž 1999.Sl. 25) and most of the fragments made with this fabric could belong to the same pot, as suggested by their technological characteristics and decoration (see Tomaž 1999.T. B1.9-14). This fabric is similar to fabrics from Resnikov prekop (fabric RP-5) and Maharski prekop (fabric MP-4).

Fabric BR-2 (Fig. 3E) is present in only one sample from the lowest layer in trench I. The fabric is a noncalcareous clay, with frequent (30\%) non-plastic inclusions, composed of frequent monocrystalline quartz, frequent muscovite and rare biotite mica, a few opaque grains, very rare organic matter and very rare grog inclusions (Tab. 4). Around 1\% of quartz grains was in the coarse sand to gravel (1-3mm) fraction, sub-angular and well sorted; these grains could have been added to a very fine natural clay paste with frequent muscovite and quartz in the silt fraction; also, very rarely, grog was added to the paste as temper. The sample has less biotite than fabric BR-1 and no chert, sandstone or limestone grains. Only five fragments from trench I were made with a similar fabric, with no calcite or limestone grains, but such characteristics were typical of most of the fragments from trench II (Tomaž 1999.Sl. 25). This fabric has no similarities with the fabrics from Resnikov prekop or Maharski prekop.

Fabric BR-3 is a non-calcareous clay, with common (20\%) non-plastic inclusions and added calcite temper. The calcite grains are frequently present, semiangular and poorly sorted; the majority of grains are in the fine to coarse sand fraction, and were added as temper to the clay paste. Other non-plastic inclusions are frequent monocrystalline quartz, a few muscovite mica and opaque grains, very few chert and very rare organic matter (Tab. 4). This fabric differs from the other two in the calcite temper, as well as in the absence of biotite mica, which is present in all the other fabrics from Breg, Resnikov prekop and Maharski prekop. The fabric was rare at Breg, since only three fragments from trench I and four fragments from trench II were made with added calcite grains as temper (Tomaž 1999.Sl. 25). This fabric is made with the same potter's recipe as fabric RP-8 from Resnikov prekop and fabric MP-1 from Maharski prekop, but the composition of non-plastic inclusions differs at this site, mostly in the absence of biotite mica grains.

\section{Origin of the clay pastes and temper}

\section{Lake marl as raw material for pottery?}

Ljubljansko Barje is a tectonic depression filled with Pleistocene sediments such as clays, silts, sands and gravel that were mostly transported to this area by rivers and streams (e.g., Iška, Ižica, Želimeljščica etc.). The main rock type of this depression is Triassic dolomite from the Noric-Rhetic stage (Buser 1965). Archaeological sites excavated in the eastern part of this region showed that the preserved wo-

\begin{tabular}{|llcccccccc|}
\hline $\begin{array}{l}\text { Fabric } \\
\text { groups }\end{array}$ & Sample No. & $\begin{array}{c}\text { Calcite } \\
\text { (in \%) }\end{array}$ & $\begin{array}{c}\text { Limestone } \\
\text { (in \%) }\end{array}$ & $\begin{array}{c}\text { Sandstone } \\
\text { (in \%) }\end{array}$ & $\begin{array}{c}\text { Quartz } \\
\text { (in \%) }\end{array}$ & $\begin{array}{c}\text { Chert } \\
\text { (in \%) }\end{array}$ & $\begin{array}{c}\text { Muscovite } \\
\text { (in \%) }\end{array}$ & $\begin{array}{c}\text { Biotite } \\
\text { (in \%) }\end{array}$ & $\begin{array}{c}\text { Opaques } \\
\text { (in \%) }\end{array}$ \\
\hline Fabric BR-1 & BR7, BR7 & 0 & $<0.5$ & 1 & 40 & $<0.5$ & 20 & 10 & $15-20$ \\
\hline Fabric BR-2 & BR6 & 0 & 0 & 0 & 40 & 0 & 40 & 1 & 15 \\
\hline Fabric BR-3 & BR5 & 30 & 0 & 0 & 40 & 5 & 10 & 0 & 10 \\
\hline
\end{tabular}

Tab. 4. The basic mineralogical composition of the thin-section of vessels from Breg near Škofljica. 
oden piles were all driven into the lake marl, called polžarica because of its abundant mollusc content. This sediment was part of a bigger lake that existed on the Ljubljansko Barje in the Pleistocene before it dried out. The sediment is very fine grey carbonaceous clay, with many mollusc shells and preserved diatoms that point to a lacustrine environment (Pavlovec 1967; Grimšičar, Ocepek 1967; Golyeva 2006.118-119). The theory that this sediment was used for pottery production in the Neolithic and Eneolithic period was debated for decades. Several authors dismissed the idea (Korošec 1964.29; Grimšičar, Ocepek 1967.294), but others maintained that the material was suitable for pottery production (Osterc 1975.125).

To test the idea of the suitability of lake marls as potting clay, a sample from the Maharski prekop canal was acquired and then prepared into three small $3 \times 4 \mathrm{~cm}$ plates and fired in a controlled oxidising temperature at $700^{\circ} \mathrm{C}, 900^{\circ} \mathrm{C}$ and $1100^{\circ} \mathrm{C}$, respectively, for three hours. 1 The dominant calcite content of the samples started decomposition into lime at $700^{\circ} \mathrm{C}$, causing the sample to crumble into dust after firing. The same happened to both samples fired at higher temperatures: they maintained neither strength nor shape after firing. Since pottery from Resnikov prekop, Maharski prekop and Breg near Škofljica had no mollusc shells preserved and was mostly made from non-calcareous clays, and combining this with the fact that lake marls are unsuitable for making pottery, we can conclude that polžarica was not used by Neolithic and Eneolithic potters in the Ljubljansko barje. Therefore, Valerija Osterc's interpretation (Osterc 1975.125) of the petrographical and X-ray diffraction results of pottery from Maharski prekop and Resnikov prekop that lake marl was probably used as the main material for pottery can be disproved.

\section{Clays from Gornje mostišče}

Following the premise that prehistoric potters selected materials for pottery production in an area of $5-7 \mathrm{~km}$ from the settlement (see Arnold 1985) and the successful use of petrographical analyses of local clays and pottery (see Whitbread 1995; Quinn et al. 2010), some additional samples of local sediments and clays were obtained from Ljubljansko Barje. At Resnikov prekop, sedimentological and biomorph analyses were already performed during the excavation in 2002 (Velušček 2006). The sedimen- tological analysis of the excavated layers showed the presence of limestone, tuff, sandstone, dolomite, and chert in grains larger than 2mm (Turk 2006. 94-96). The biomorph analysis showed the presence of diatoms in the lake marl and sponge spicules and phytoliths in the layers above (Golyeva 2006.117-119).

For the petrographical analysis, we sampled three types of clays from Gornje mostišče (Fig. 1) during a smaller-scale excavation of test trenches in 2012. The site is located near Maharski prekop and Resnikov prekop on an isolated hill. Excavations here showed the presence of a new type of settlement, with a long-term accumulation of anthropogenic activities in the area (the material is not yet published; see Mlekuž 2013). The samples came from two test trenches: grey silty clay (sample GM1) was obtained below the excavated wooden platform at the northern trench, and light brownish grey very fine-grained clay (sample GM3) as well as very dark organic clay (sample GM4) came from the trench near the Resnikov prekop canal, where no traces of human activity were found (Mlekuž 2013).

The Gornje mostišče samples were analysed with the X-ray diffraction method in their natural state and also prepared as approx. $3 \times 4 \mathrm{~cm}$ plates and fired in a controlled oxidising temperature at $700^{\circ} \mathrm{C}$ for three hours. After firing, the samples were prepared as standard thin sections and described under a polarising optical microscope, following Ian Whitbread (1995.Appendix 3). All the samples are non-calcareous clays, with frequent (30-40\%) non-plastic inclusions comprised of frequent quartz, frequent muscovite and common biotite mica, a few opaque grains, rare plagioclase feldspars and rare chert (Tab. 5). Two samples (GM1 and GM3) contained very little dolomite, as shown with the X-ray diffraction method, and this was already decomposing to mineral periclase at $700^{\circ} \mathrm{C}$, which could be observed in thin section (Cultrone et al. 2001.630). The sample of very fine clay (GM3) also yielded very rare sponge spicules in the petrographic analysis and the silty clay below the wooden platform also had rare sandstone grains (Fig. 3F).

The Gornje mostišče samples show a similar mineralogical composition to the natural clay pastes in vessels from Resnikov prekop, Maharski prekop and Breg near Školfjica. Sample GM3 from Gornje mo-

1 The clay samples were fired at temperatures high enough for the reaction of dehydroxylation of clay minerals to occur; it was reported that in $\mathrm{T}<700^{\circ} \mathrm{C}$ no significant mineralogical or textural changes occur in clays (Cultrone et al. 2001.629). 


\begin{tabular}{|lccccccccc|}
\hline $\begin{array}{l}\text { Sample } \\
\text { No. }\end{array}$ & $\begin{array}{c}\text { Quartz } \\
\text { (in \%) }\end{array}$ & $\begin{array}{c}\text { Chert } \\
\text { (in \%) }\end{array}$ & $\begin{array}{c}\text { Sandstone } \\
\text { (in \%) }\end{array}$ & $\begin{array}{c}\text { Muscovite } \\
\text { (in \%) }\end{array}$ & $\begin{array}{c}\text { Biotite } \\
\text { (in \%) }\end{array}$ & $\begin{array}{c}\text { Periclase } \\
\text { (in \%) }\end{array}$ & $\begin{array}{c}\text { Feldspars } \\
\text { (in \%) }\end{array}$ & $\begin{array}{c}\text { Opaques } \\
\text { (in \%) }\end{array}$ & $\begin{array}{c}\text { Spicules } \\
\text { (in \%) }\end{array}$ \\
\hline $\mathrm{GM}_{1}$ & 40 & 2 & 2 & 30 & 15 & 2 & 0.5 & 15 & 0 \\
\hline $\mathrm{GM}_{3}$ & 50 & 2 & 0 & 30 & 15 & 0 & 2 & 5 & 0.5 \\
\hline $\mathrm{GM}_{4}$ & 40 & 0.5 & 0 & 30 & 15 & 5 & 0.5 & 5 & 0 \\
\hline
\end{tabular}

Tab. 5. The basic mineralogical composition of the thin-section of fired clay samples from Gornje Mostišce on the Ljubljansko barje.

stišče is a very fine clay that would be suitable for the making of pottery and had the most similar mineralogical composition to the analysed Neolithic and Eneolithic vessels from this area. Similar grey to light brown clay deposits were also documented above the archaeological layers at Resnikov prekop (Bregant 1964.14-15; Harej 1975. 146) as well as at Maharski prekop (here interpreted as alluvial sediment covering most of the site in a flood; Bregant 1974a.8-9; 1974b.40-41; 1975.12-13). Clearly this clay is younger than the pottery taken from Resnikov prekop and Maharski prekop, since it covers the cultural layers at the sites; however, a similar very fine alluvial sediment that was transported by rivers from the karstic outskirts probably existed in the Barje floodplain in the Neolithic and Eneolithic period and was later removed from the area by seasonal floods. The fact that a substantial quantity of sediments was removed in this period was attested at Resnikov prekop and other sites (see Velušček 2006; Budja, Mlekuž 2008; Verbič 2011).

\section{The origin of fabric RP-1}

The vessels made with pastes containing sponge spicules from Resnikov prekop are also of particular interest (fabric RP-1; Fig. 2A). Some sponges are made of a mineral skeleton of siliceous structures termed spicules and an organic skeleton of collagen. Three general categories of spicules are called megascleres, microscleres and gemmoscleres. Megascleres are needle-shaped structures that range in length from 150 to $450 \mu \mathrm{m}$ (Thorp, Covich 2010.94-95, Fig. 4.7; Fig. 4.28) and, due to their size, can be recognised at low magnification. Freshwater sponges produce much smaller spicules than marine sponges; they are typically silt rather than sand-sized. All freshwater sponges belong to the class Demospongiae and include a distinct suborder called the Spongillina (Thorp, Covich 2010. 105) which is found not only in lakes and rivers, but also bogs and waterlogged soils. They have been found to date in the soils of all continents except Antarctica (see Clarke 2003 with references). Surface soil samples can contain from 1 to $30 \%$ sponge spicules; the highest counts come from poorly drained soils such as lakes or ponds. Whole spicules are usually preserved in very wet areas, and broken and pitted spicules were probably moved by water or wind (Schwandes, Collins 1994. 243-255).

The biomorph analysis of soil samples from the 2002 excavations at Resnikov prekop showed the presence of phytoliths, diatoms and sponge spicules (Golyeva 2006). The soils from Resnikov prekop yielded many unbroken sponge spicules and phytoliths in the sample up to $120 \mathrm{~cm}$ depth; below $126 \mathrm{~cm}$, diatoms typical of lacustrine deposits were the most common. Freshwater sponges indicate soils subject to flooding, such as alluvial soils, and their content in a soil sample may be indicative of the duration and intensity of floods at the studied site. These results indicate that Resnikov prekop was under hydromorphic conditions all the time, with a lake at the beginning, and later with a stream or small river (perhaps only seasonally) present at this site (Golyeva 2006.116-119).

The presence of unbroken sponge spicules in fabric RP-1 at Resnikov prekop shows that the clay for these vessels was gathered locally, as shown by the similar mineralogical composition and presence of spicules from clay sample GM3 at Gornje mostišče, and the presence of spicules in the layers above the lake marl at the excavations in 2002. Nevertheless, the higher number of spicules counted in the pottery could point to clay gathered in a pond or small lake, not near a river or stream. This hypothesis will be tested in the future with new clay samples from this area.

\section{The origin of tempering materials}

If we take a closer look at the different tempers used in the production of pottery in the Neolithic and Eneolithic on Ljubljansko barje, we see that tempering material such as quartz sand, chert, various types of sandstones and limestone (as seen in fabrics $\mathrm{RP}-3, \mathrm{RP}-4, \mathrm{RP}-5, \mathrm{RP}-6, \mathrm{MP}-4, \mathrm{BR}-1)$ are an integral part of various Pleistocene sediments in this area (Busar 1965; Turk 2006). Therefore, this temper could have been collected near the settlements. This also applies to the use of grasses and similar organic material as temper, as shown in fabric MP-3 
at Maharski prekop. Nonetheless, potters probably had to travel longer distances to collect calcite as temper, since a pure form of calcite is not present in this area, where limestone and dolomite are more common, but could be acquired on the karstic outskirts south of the Ljubljanske barje, where this mineral is present as veins in limestone or as speleothems in caves (Gams 2004.361-364). Further proof that calcite was indeed collected on the outskirts of Barje is the presence of calcite and limestone blocks found at the Stare gmajne pile-dwelling (Turk 2009. 284). As shown above, calcite temper was the most frequently used recipe at Maharski prekop (fabric MP-1), but is also present in about $25 \%$ of the samples from Resnikov prekop (fabric RP-8) and is rare at Breg near Škofljica (fabric BR-3).

In Ljubljansko barje, the calcite-tempered fabric was present from the earliest stages of pottery production, and was used in the production process in a third of the vessels made at Resnikov prekop and Breg. The fabric with calcite temper later became the most common recipe in Ljubljansko barje area, as demonstrated in the Eneolithic pottery production at Maharski prekop. The tradition of using calcite as an important raw material in the making of ceramic vessels has a long tradition in the Barje, as well as in western parts of Slovenia. The vessels from the Vlaška group found in caves and rock shelters in the Karst are made with this fabric, and this pottery tradition remains dominant through the Neolithic and Eneolithic period (Žibrat Gašparič 2004; 2008). Other contemporaneous sites from central, southern and eastern parts of Slovenia show the preference for other recipes and technologies (see Tomaž 1999; 2005; Turk, Svetličič 2005; Žibrat Gašparič 2008. 127-174; Kramberger 2010.312, 317).

The use of calcite temper was a technological choice of Neolithic and Eneolithic potters, since experiments have shown that the greater toughness and higher thermal shock resistance useful for cooking pots are achieved by a high concentration of temper (especially limestone/calcite, shell or grog temper) and low firing temperatures (Tite et al. 2001.321). On the other hand, it has also been suggested, based on the earliest Neolithic pottery from Franchthi cave in Greece, that the use of calcium carbonate as temper was a shamanic procedure and the glittering calcite crystals were important in the mystical or curative powers of the recipe. This makes sense in connection with the observation that in the Early Neolithic the process of making pottery was more important than the actual product (Vitelli 1999.193). Calcite was probably seen as valuable material by the people from Maharski prekop. They used calcite abundantly in pottery production, but also made jewellery from its crystals, which is demonstrated by a necklace made from 33 calcite beads, and several individual beads were found at the site (Bregant 1984b.49, T. 4.11; 1975.30, T. 8.15-17, 19, T. 12.1; Strmole 1974).

We can also regard crushed pottery or grog temper in a similar fashion. This fabric is known only from Maharski prekop, and even there in only a handful of pots (see fabric MP-2). Here, the choice of grog as tempering material could represent renewal or memory of the deceased, but can be also linked to potters' individual choice and artistic expression (Quinn, Burton 2009.288).

\section{Pottery traditions in Ljubljansko barje}

The operational sequence or chaîne opératoire at Resnikov prekop, Maharski prekop and Breg included the selection of raw materials from a local area of less than $5 \mathrm{~km}$ for clay and more than $5 \mathrm{~km}$ for the acquisition of tempering materials, especially calcite. Therefore, potters used mostly locally available raw materials, although it is known that they had connections with other areas, shown especially in the use of different stone materials procured more than $100 \mathrm{~km}$ to the north, west and south of Ljubljansko barje (Bernardini et al. 2009). Potters used various fabrics in the preparation of clay bodies: at least eight different fabrics (RP-1 to RP-8) were recognised at Resnikov prekop, four at Maharski prekop (MP-1 to MP-4) and three at Breg near Škofljica (BR-1 to BR-3). Certain fabrics were used at all of the sites, such as the fabric with added calcite temper (fabric $\mathrm{RP}-8, \mathrm{MP}-1$ and $\mathrm{BR}-3$ ) or the fabric with added sandstone temper (fabrics RP-5, MP-4 and BR-1). The pottery from all three analysed sites was produced using mostly local materials, but with different recipes or fabrics. Similarly, the clays used by potters show some variability, especially at Resnikov prekop, which suggests that a variety of different locally available natural sources was used.

After the preparation of clays and temper, the pots were mostly made with the coiling technique (Bregant 1975.34-35), which is typical of pottery production in a household economy and where pottery making is only a part-time occupation (Arnold 1985). For smoothing and burnishing the vessels surfaces, various tools were used, such as the bone tools discovered at Maharski prekop (Bregant 1974a.T. 4.3, T. 
7.3; 1974b.T. 4.1-2; 1975.T. 8.8, T. 12.7). Areas for pottery production, such as the remains of kilns or firing sites have not been discovered in this region. The pottery from Resnikov prekop and Breg was mostly fired in an open firing, since most of the vessels were fired in an incomplete atmosphere. However, pottery from Maharski prekop was probably fired in kilns in a reducing atmosphere (Bregant 1974b.50). This is supported by the fact that the pottery had well-preserved organic matter in the fabrics, typical of ceramics fired in a reducing rather than oxidising atmosphere (Reedy 2008.185-180), and the fact that copper metallurgy was known and used at the settlement (Velušček, Greif 1998). Wood for fuel (as well as an important building material) could have been acquired in the vicinity, south of the settlement on the outskirts of the Barje region (Bregant 1975.17-30; Šercelj 1975.115-120).

The optically active clay paste as observed under the microscope shows that the pottery was not fired at very high temperature. At around $600^{\circ} \mathrm{C}$, clay minerals lose their water of hydration and this marks major alterations in their chemical and minerals structures. At around $900^{\circ} \mathrm{C}$, their structures collapse irreversibly and clay minerals lose their optical characteristics (Grimshaw 1971.221-227; Rice 1987.9092). Additionally, the fabrics with calcite and limestone inclusions show that these minerals were not fired to the temperature of calcite decomposition into lime, which occurs in the 650 to $850^{\circ} \mathrm{C}$ temperature interval (Rice 1987.97-98; Cultrone et al. 2001.624). This reaction starts at a lower temperature when pottery is fired in oxidising conditions and at higher temperatures in reducing conditions (Reedy 2008.187-189). In most of the fabrics, the monocrystalline quartz grains exhibit shattering of the grains connected to the first inversion reaction, typical of this mineral, which starts at $573^{\circ} \mathrm{C}(\mathrm{Grim}$ shaw 1971.221-227). Since pottery from all three sites in Ljubljansko barje exhibits similar changes in the mineralogical composition of fabrics, we conclude that the pottery with calcite or limestone inclusions was fired at lower temperatures, between 600 to $700^{\circ} \mathrm{C}$, which is typical of pottery of this period (Žibrat Gašparič 2004.212-213; 2008.86-88). Nevertheless, the fabrics without calcareous inclusions could have been fired to $800^{\circ} \mathrm{C}$, but not significantly higher, since muscovite and biotite mica grains did not start to transform into higher temperature minerals such as mullite (Cultrone et al. 2001.624).

The oldest pottery tradition in Ljubljansko barje is linked to vessels at Resnikov prekop, since the mak- ing of ceramic vessels was performed at the site already in the $6^{\text {th }}$ millennium calBC, as was proved with new radiocarbon dates. The typological analysis of vessels from Resnikov prekop shows great variability, with various types of pots being the most common. In addition, dishes, footed dishes, bowls, cups, pitchers, beakers and lades are also present. Pots and dishes were made from all the fabrics recognised at Resnikov prekop; however, bowls, cups, beakers and jugs were mostly made of fabrics with added quartz, sandstone or limestone temper (fabrics $\mathrm{RP}-5$ and $\mathrm{RP}-6$ ) and only rarely with added calcite (RP-8) or with a very fine-grained clay (RP-2). Since different fabrics and recipes were used for the production of similar vessel types, we can assume that they reflect the personal choice of potters. The predominant lipid content was of ruminant fats and mixed fats, but also milk in one of the bowls (Mlekuž et al. 2013; bowl - Harej 1975.T. 3.7).

The pottery tradition from Breg near Škofljica resembles the material from Resnikov prekop, although the few excavated vessels also exhibit special characteristics not present in the pottery from Resnikov prekop. In vessel typology, the pottery assemblage from Breg is modest, since only one vessel could be reconstructed: one pot decorated with grooved incisions (Tomaž 1999.T. B1.9) which is similar to pots from Resnikov prekop. The petrographic analysis showed that similar decorated fragments found at Breg were all part of the same pot (Tomaž 1999.T. 1.10-14), making the number of possible vessels found at the site even smaller. The total number of possible different vessels at Breg is below twenty and the pottery was made from at least three different fabrics, two of which resemble fabrics from Resnikov prekop, which makes for great variability in a small assemblage, which could reflect individual choices by potters.

The other pottery tradition is linked to the younger assemblage at Maharski prekop. The vessels from Maharski preko show great variability in their shapes and dimensions, and we propose that they had different functions, as serving and cooking vessels as well as for storage (Mlekuž et al. 2012.332-336). This is further supported by the fact that the four fabrics are not correlated to vessel types; for example, the most common fabric, MP-1, was used for a series of different vessel types that had different functions and their function was not predetermined during production (Mlekuž et al. 2012.336; Ogrinc et al. 2012.346). The pottery assemblage from Maharski prekop shows a long tradition in pottery pro- 
duction, spanning almost 900 years, according to new radiocarbon dates (Mlekuž et al. 2012.T. 1). This tradition included the use of four pottery fabrics, the predominant use of calcite temper and the use of local raw materials.

\section{Conclusions}

Every pot encountered at archaeological sites is the result of a series of decisions made by the potters, who had a choice of various natural raw materials, tools, sources of energy and manufacturing techniques. Consequently, each pot is a unique result of a potter who had a choice between alternative techniques. Pottery technology analyses should therefore focus on the whole operational sequence in pottery production, which involves the manipulation of tools as well as natural resources within local cultural perceptions of the suitability of certain methods and techniques (Sillar, Tite 2000.3-4). The development of technological traditions comes from an interaction between the more conservative cultural choice and the more innovative nature of personal choice. Prehistoric potters only rarely recognised all the potential manufacturing techniques for pottery production and used only a handful; the techniques used were probably considered as traditional inside a community and were learnt from other potters. Innovations did happen mostly if the innovator obtained materials, tools or techniques from a different sphere of technological activities and modified them for his/her needs (Sillar, Tite 2000.10). Therefore, pottery technology should be considered in comparison with other contemporaneous techniques, since all techniques are choices made in the wider contexts of local perceptions (Lemmonier 1986) and are the result of different practical possibilities that were evaluated and chosen through cultural criteria (Silar, Tite 2000.7-9).

The operational sequence at the Neolithic and Eneolithic sites on the Ljubljansko barje included the procurement of raw materials locally, but also over an area more than $5 \mathrm{~km}$ from the sites, which was a common procedure in all the analysed pottery traditions. Nevertheless, the preparation of pottery fabrics, the shaping and decorating, as well as firing of the vessels were different in traditions at Resnikov prekop and Breg from those at Maharski prekop. At the oldest settlements at Resnikov prekop and Breg, the potters used a variety of different recipes for their pots, dishes, bowls, cups etc., although the vessels have a very similar general appearance. In addition, the fabrics used for pottery at Resnikov prekop and Breg show that the potters used different types of raw materials, probably procured locally, but at different locations. At the moment, we cannot explain whether clay and tempering materials were collected even farther away than $5 \mathrm{~km}$ on the Ljubljansko barje or on its fringes, since only a handful of clay samples have been analysed thus far. The choice of different natural raw materials in a small area could be related to the individual potters working at these sites. On the other hand, at the younger Maharski prekop site, the number of different recipes, fabrics and clays dropped significantly and the vessels show a very strong tradition, and appear more homogenous in their preparation, shapes and decoration, although they had different functions.

The selection of raw material, the shaping and decorating of pots, their firing and use were probably more related to different traditions and individual choices of potters at these sites than being purely technological choices. This can be seen in the use of a variety of different tempers and clay pastes acquired near the settlements on the flood plain as well as on the karstic fringes. Some materials could have had a special position for these prehistoric potters and their communities, such as the addition of calcite, which was also used for personal ornaments, and crushed pottery or grog. In addition, other raw materials, especially stone tools and ornaments, were acquired from distances far from Ljubljansko barje (e.g., Skaberne, Mladenovič 2004; Bernardini et al. 2009), supporting the idea that different materials had different meanings for the Neolithic and Eneolithic communities in this area and that their choices were not always based on the best technological solutions or the nearest procurement sites.

\section{ACKNOWLEDGEMENTS}

The research was undertaken as part of research project J6-4085 funded by the Slovenian Research Agency. I would like to thank the Ljubljana City Museum and Irena Šinkovec for providing access to the Resnikov prekop and Maharski prekop pottery assemblages. 


\section{References}

Arnold D. E. 1985. Ceramic theory and cultural process. Cambridge University Press. Cambridge.

Bernardini F., Montagnari Kokelj E., Demarchi G. and Alberti A. 2009. Scambi e strategie di approvvigionamento nel Ljubljansko barje del IV millennio a.C. dedotti dallo studio archaeometrico di manufatti in pietra. In A. Velušček (ed.), Koliščarska naselbina Stare gmajne in njen čas / Stare gmajne pile-dwelling settlement and its era. Opera Instituti Archaeologici Sloveniae 16. Inštitut za arheologijo ZRC SAZU. Založba ZRC. Ljubljana: 251-279.

Bregant T. 1964. Poročilo o raziskovanju kolišča in gradbenih ostankov ob Resnikovem prekopu pri Igu. Poročilo o raziskovanju neolita in eneolita $v$ Sloveniji 1: 7-24.

1974a. Kolišče ob Maharskem prekopu pri Igu - raziskovanja leta 1970. Poročilo o raziskovanju neolita in eneolita Slovenije 3: 7-34.

1974b. Kolišče ob Maharskem prekopu pri Igu - raziskovanja leta 1972. Poročilo o raziskovanju neolita in eneolita Slovenije 3: 39-66.

1975. Kolišče ob Maharskem prekopu pri Igu - raziskovanja 1973. in 1974. leta. Poročilo o raziskovanju neolita in eneolita Slovenije 4: 7-106.

Budja M. 1993. Neolitizacija Evrope. Slovenska perspektiva / The Neolithisation of Europe. Slovenian Aspect. POročilo o raziskovanju paleolitika, neolitika in eneolitika v Sloveniji 21: 163-193.

1994/1995. Spreminjanje naravne in kulturne krajine v neolitiku in eneolitiku na Ljubljanskem barju. Poročilo o raziskovanju paleolitika, neolitika in eneolitika $v$ Sloveniji 22: 163-181.

Budja M., Mlekuž D. 2008. Settlements, landscape and palaeoclimate dynamics on the Ižica floodplain of the Ljubljana Marshes. Documenta Praehistorica 35: 45-54.

2010. Lake or floodplain? Mid-Holocene settlement patterns and landscape dynamics of the Ižica floodplain (Ljubljana Marches, Slovenia). The Holocene 20(8): 1269-1275.

Buser S. 1965. Geološka zgradba južnega dela Ljubljanskega barja in njegovega obrobja. Geologija: razprave in poročila 8: 34-57.

Clarke J. 2003. The occurrence and significance of biogenic opal in the regolith. Earth-Science Reviews 60(3-4): 175-194.
Čufar K., Korenčič T. 2006. Investigations of Wood from Resnikov prekop and Radiocarbon Dating. In A. Velušček (ed.), Resnikov prekop. The oldest pile-dwelling settlement in the Ljubljansko barje. Opera Instituti Archaeologici Sloveniae 10. Institute of Archaeology at ZRC SAZU. ZRC Publishing. Ljubljana: 123-128.

Frelih M. 1986. Breg pri Škofljici - mezolitsko najdišče na Ljubljanskem barju. Poročilo o raziskovanju paleolita, neolita in eneolita $v$ Sloveniji 14: 21-58.

Gams I. 2004. Kras v Sloveniji v prostoru in času. Založba ZRC. Ljubljana.

Golyeva A. A. 2006. Paleoecological Reconstructions based on the Biomorphic Analysis. A Case Study: Resnikov prekop. In A. Velušček (ed.), Resnikov prekop: najstarejša koliščarska naselbina na Ljubljanskem barju / Resnikov prekop: the oldest pile-dwelling settlement in the Ljubljansko barje. Opera Instituti Archaeologici Sloveniae 10. Institute of Archaeology at ZRC SAZU. ZRC Publishing. Ljubljana: 115-122.

Grimšičar A., Ocepek V. 1967. Vrtini BV-1 in BV-2 na Ljubljanskem barju. Geologija 10: 279-303.

Grimshaw R. W. 1971. The Chemistry and Physics of Clays and Allied Ceramic Materials. London.

Harej Z. 1975. Kolišče ob Resnikovem prekopu - II. Poročilo o raziskovanju neolita in eneolita $v$ Sloveniji 4 : 145-169.

1978. Kolišče v Partih na Igu na Ljubljanskem barju. Poročilo o raziskovanju paleolita, neolita in eneolita 6: 61-94.

1981-1982. Kolišče v Partih na Igu na Ljubljanskem barju. Poročilo o raziskovanju paleolita, neolita in eneolita 9-10: 31-101.

1987. Kolišče v Partih pri Igu na Ljubljanskem barju raziskovanja leta 1981. Poročilo o raziskovanju paleolita, neolita in eneolita v Sloveniji 15: 141-194.

Horvat M. 1999. Keramika: tehnologija keramike, tipologija lončenine, keramični arhiv. Znanstveni inštitut Filozofske fakultete. Ljubljana.

Korošec J. 1964. Kulturne ostaline na kolišču ob Resnikovem prekopu odkrite v letu 1962. Poročilo o raziskovanju neolita in eneolita $v$ Sloveniji 1: 25-46.

Korošec P., Korošec J. 1969. Najdbe s koliščarskih naselbin pri Igu na Ljubljanskem barju. Arheološki katalogi Slovenije 3. Narodni muzej. Ljubljana. 
Kramberger B. 2010. Zgornje Radvanje, Cluster 10 - a Late Neolithic pit with a structure and smaller pits. Documenta Praehistorica 37: 311-337.

Lemonnier P. 1986. The Study of Material Culture Today: Toward an Anthropology of Technical Systems. Journal of Anthropological Archaeology 5: 147-186.

Melik A. 1946. Ljubljansko koliščarsko jezero in dediščina po njem. Dela SAZU 5. Ljubljana.

Mlekuž D. 2013. Poročilo o izkopu testnih jarkov na Gornjem mostišču. Unpublished report. Zavod za varstvo kulturne dediščine. Ljubljana.

Mlekuž D., Budja M. and Ogrinc N. 2006. Complex settlement and the landscape dynamic of the Iščica floodplain (Ljubljana Marshes, Slovenia). Documenta Praehistorica 33: 253-271.

Mlekuž D., Žibrat Gašparič A., Horvat M. and Budja M. 2012. Houses, pots and food: the pottery from Maharski prekop in context. Documenta Praehistorica 39: 325338 .

Mlekuž D., Ogrinc N., Horvat M., Žibrat Gašparič A., Gams Petrišič M. and Budja M. 2013. Pots and food: uses of pottery from Resnikov prekop. Documenta Praehistorica 40 : 131-146.

Ogrinc N., Gams Petrišič M., Žigon D., Žibrat Gašparič A. and Budja M. 2012. Pots and lipids: molecular and isotope evidence of food processing at Maharski prekop. Documenta Praehistorica 39: 339-347.

Osterc V. 1975. Mineralna sestava in mikrostruktura keramike s kolišča ob Maharskem prekopu I. Poročila o raziskovanju neolita in eneolita v Sloveniji 4: 123-134.

Pavlovec R. 1967. Mehkužci iz jezerske krede na Ljubljanskem barju. Geologija 10: 167-187.

Quinn P., Burton M. 2009. Ceramic petrography and the reconstruction of hunter-gatherer craft technology in Late Prehistoric southern California. In P. S. Quinn (ed.), Interpreting silent artefacts. Petrographic Approaches to Archaeological Ceramics. Archaeopress. Oxford: 267-295.

Quinn P., Day P., Kilikoglou V., Faber E., Katsarou-Tzeveleki S. and Sampson A. 2010. Keeping an eye on your pot: the provenance of Neolithic ceramics from the Cave of the Cyclops, Youra, Greece. Journal of Archaeological Science 37: 1042-1052.

Reedy C. L. 2008. Thin-Section Petrography of Stone and Ceramic Cultural Material. Archetype Publications. London.
Rice P. M. 1987. Pottery Analysis. A Sourcebook. The University of Chicago Press. Chicago and London.

Schwandes L. P., Collins M. E. 1994. Distribution and Significance of Freshwater Sponge Spicules in Selected Florida Soils. Transactions of the American Microscopical Society 133(3): 242-257.

Sillar B., Tite M. S. 2000. The challenge of 'technological choices' for materials science approaches in archaeology. Archaeometry 42(1): 2-20.

Skaberne D., Mladenovič A. 2004. Opredelitev materiala ogrličnega obročka s Hočevarice / Determination of necklace ringlets material frm Hočevarica. In A. Velušček (ed.), Hočevaric: eneolitsko kolišče na Ljubljanskem barju / Hočevarica: an Eneolithic pile-dwelling in the Ljubljansko barje. Opera Instituti Archaeologici Sloveniae 9. Inštitut za arheologijo ZRC SAZU. Založba ZRC. Ljubljana: 6568.

Stritar A. 1975. Pedološke raziskave kolišča ob Maharskem prekopu pri Igu - 1973. leta. Poročilo o raziskovanju neolita in eneolita $v$ Sloveniji 4: 142-144.

Strmole D. 1974. Poročilo o mineraloški preiskavi ogrlice s kolišča ob Maharskem prekopu pri Igu - raziskovanja leta 1972. Poročilo o raziskovanju neolita in eneolita $v$ Sloveniji 3: 72.

Šercelj A. 1966. Pelodne analize pleistocenskih in holocenskih sedimentov Ljubljanskega barja. Razprave $S A Z U$ 9: 429-472.

1974. Poročilo o ksilotonskih raziskavah kolišča ob Maharskem prekopu - raziskovanja leta 1972. Poročilo o raziskovanju neolita in eneolita $v$ Sloveniji 3: 69-70.

1975. Analize makroskopskih in mikroskopskih rastlinskih ostankov s kolišča ob Maharskem prekopu, izkopavanja 1973. in 1974. leta. Poročilo o raziskovanju neolita in eneolita $v$ Sloveniji 4: 115-122.

Terry R., Chilingar G. 1955. Summary of 'Concerning some additional aids in studying sedimentary formations' by M. S. Shvetsov. Journal of Sedimentary Research 25: 229-234.

Thorp J. H., Covich A. P. 2010. Ecology and Classification of North American Freshwater Invertebrates. Academic Press. London/Burlington/San Diego.

Tite M. S., Kilikoglou V. and Vekinis G. 2001. Strength, toughness and thermal shock resistance of ancient ceramics, and their influence on technological choice. Archaeometry 43(3): 301-324. 
Tomaž A. 1999. Časovna in prostorska strukturiranost neolitskega lončarstva: Bela Krajina, Ljubljansko barje, Dinarski kras. Unpublished MA thesis. Faculty of Arts. University of Ljubljana. Ljubljana.

2005. Čatež-Sredno polje. Analiza neolitske keramike iz objektov 055 in 093. In M. Guštin (ed.), Prvi poljedelci. Savska skupina Lengyelske culture / First Farmers: The Sava Group of the Lengyel Culture. Založba Annales. Koper: 113-129.

Tomaž A., Velušček A. 2005. Resnikov prekop na Ljubljanskem barju 1962 in 2002 (Resnikov prekop in the Ljubljansko barje 1962 and 2002). In M. Guštin (ed.), Prvi poljedelci. Savska skupina Lengyelske culture / First Farmers: The Sava Group of the Lengyel Culture. Založba Annales. Koper: 87-100.

Turk P., Svetličič V. 2005. Neolitska naselbina v Dragomlju. In M. Guštin (ed.), Prvi poljedelci. Savska skupina Lengyelske culture / First Farmers: The Sava Group of the Lengyel Culture. Založba Annales. Koper: 65-79.

Turk J. 2006. Ugotavljanje paleoekoloških sprememb na Ljubljanskem Barju v holocenu na primeru sedimentov z Resnikovega prekopa / Determining paleoecological changes in the Ljubljansko barje during the Holocene - case study: Resnikov prekop. In A. Velušček (ed.), Resnikov prekop: najstarejša koliščarska naselbina na Ljubljanskem barju / Resnikov prekop: the oldest pile-dwelling settlement in the Ljubljansko barje. Opera Instrituti Archaeologici Sloveniae 10. Inštitut za arheologijo ZRC SAZU. Založba ZRC. Ljubljana: 93-98.

2009. Petrološka sestava in izvor kamnitih najdb z najdišč Stare gmajne in Blatna Brezovica / Petrological composition and origin of stone finds from the sites Stare gmajne and Blatna Brezovica. In A. Velušček (ed.), Koliščarska naselbina Stare gmajne in njen čas / Stare gmajne pile-dwelling settlement and its era. Opera Instituti Archaeologici Sloveniae 16. Inštitut za arheologijo ZRC SAZU. Založba ZRC. Ljubljana: 281-286.

Velušček A. (ed.) 2004. Hočevarica: eneolitsko kolišče na Ljubljanskem barju / Hočevarica: an Eneolithic piledwelling in the Ljubljansko barje. Opera Instituti Archaeo- logici Sloveniae 9. Inštitut za arheologijo ZRC SAZU. Založba ZRC. Ljubljana.

(ed.) 2006. Resnikov prekop: najstarejša koliščarska naselbina na Ljubljanskem barju / Resnikov prekop: the oldest pile-dwelling settlement in the Ljubljansko barje. Opera Instituti Archaeologici Sloveniae 10. Inštitut za arheologijo ZRC SAZU. Založba ZRC. Ljubljana.

2007. Prispevek k diskusiji o preocesu neolitizacije. $A r$ heološki vestnik 58: 425-434.

(ed.) 2009. Koliščarska naselbina Stare gmajne in njen čas / Stare gmajne pile-dwelling settlement and its era. Opera Instituti Archaeologici Sloveniae 16. Inštitut za arheologijo ZRC SAZU. Založba ZRC. Ljubljana.

Velušček A., Greif T. 1998. Talilnik in livarski kalup z Maharskega prekopa na Ljubljanskem barju. Arheološki vestnik 49: 31-53.

Verbič T. 2011. The sedimentary environment in the Ljubljansko barje basin during the pile-dwelling period. $A r$ heološki vestnik 62: 89-109.

Vitelli K. D. 1999. "Looking Up" at Early Ceramics in Greece. In J. M. Skibo, G. M. Feinman (eds.), Pottery and People. A Dynamic Interaction. The University of Utah Press. Salt Lake City: 184-198.

Whitbread I. K. 1991. Image and Data Processing in Ceramic Petrology. In A. P. Middleton, I. C. Freestone (eds.), Recent Developments in Ceramic Petrology. British Museum Occasional Paper 81: 369-388.

1995. Greek Transport Amphorae. A Petrological and Archaeological Study. Fitch Laboratory Occasional Paper 4. The British School at Athens. Exeter.

Žibrat Gašparič A. 2004. Archaeometrical analysis of Neolithic pottery from the Divača region, Slovenia. Documenta Praehistorica 31: 205-220.

2008. Strukturna analiza neolitske keramike in lončarske tehnologije. Unpublished $\mathrm{PhD}$ thesis. Faculty of Arts. University of Ljubljana. Ljubljana. 